\title{
Analysis on Handling Community Cultural Values Erosion in Semarang, Indonesia
}

\author{
Hardi Warsono \\ Departement of Public Administration \\ Diponegoro University \\ Semarang, Indonesia \\ hardie_wsn@yahoo.com
}

\author{
Dyah Hariani \\ Departement of Public Administration \\ Diponegoro University \\ Semarang, Indonesia \\ dyahhariani@gmail.com \\ Sarwo Edy \\ Departement of Public Administration \\ Diponegoro University \\ Semarang, Indonesia
}

\begin{abstract}
Globalization era, cultural value erosion in Indonesia, the declining interest and public concern of Semarang city people to art and culture, and the performance of Culture and Tourism Office are the backgrounds of this study. This research aims to analyze the performance of Culture and Tourism Office (CTO) in dealing with cultural value erosion of Semarang people. This study uses the theory of organizational performance with five dimensions of organizational performance, i.e. productivity, service quality, responsiveness, responsibility, and accountability, as well as enabling and inhibiting factors derived from the internal and external environments. This research used qualitative descriptive approach. Techniques of collecting data are interviews, documentation, and literature study with Culture and Tourism Office employees as the informants. The results showed that the performance of $\mathrm{CTO}$ in handling cultural values erosion of Semarang people is good, but not maximal yet because there are constraints on the dimensions of productivity and service quality, the lack of coordination and cooperation and the lack of community participation. Supporting factors are objectives in Strategic Plan of CTO year 2010-2015, CTO organizational structure is very good, qualified human resources, the attitude of discipline and mutual cooperation, Strategic Planning (RPJMD) policy, economic conditions and their budgets, community participation during big events, and public criticism and suggestions. While the inhibiting factors are limited human resources, regulations, strict policy from central and local government about the grant, the absence of authority in national film industry, certification of cultural heritage, and preservation of Javanese language, limited budget, and lack of participation, public interest and awareness to culture conservation.
\end{abstract}

Keywords: globalization; performance; cultural value

Corresponding authors: Hardi Warsono

\section{INTRODUCTION}

Globalization is an era of openness and freedom which brings positive and negative impacts in a country, including Indonesia. One of positive impacts is the rapid progress of Science and Technology. This is shown by the development of information technology and Communication. Distance is now not a barrier in interaction activity. This trigger the negative impact of globalization. Foreign (developed countries) cultural values (which are often not appropriate with cultural values) which are actually the main actors of globalization today are widely spread over and adhered rapidly by developing countries including Indonesia. Today, foreign cultural values which have long entered our country increasingly erode the local cultural values that we own, such as folklore, regional songs, regional rituals, regional customs, and so on.

Based on the preceding description, it can be concluded that Culture and Tourism Office (CTO) of Semarang City plays an important role and has authority in dealing with solving Cultural Values Erosion (afterward called CVE) in Semarang City. The researchers chose the study of observation in Culture Sector, as Culture Sector is one of the areas handling Local government affairs in the field of culture. The problem of CVE of Semarang people has become one of the strategic issues in Strategic Plan (Renstra) of CTO of Semarang City in 2010-2015. One of the manifestations of handling CVE is by maintaining cultural conservation of both objects and non-cultural objects owned by Semarang City. Semarang city as one of many cultural cities in Indonesia has a long history and has grown for 468 years. It also has various cultural potentials and heritages in the form of both objects and non-objects that are developed and inherited through generations, such as buildings (Lawangsewu, Kauman Mosque and Layur, Blenduk church, Tambaksari Station, Tay Kak Sie Shrine, Tanjung Mas Lighthouse, and many others) and non-object cultural heritages which have received international recognition (batik, keris, leather wayang) and national recognition (lumpia, presto milkfish, warak ngendhok). 
We can observe this phenomenon from the number of art groups in Semarang City for the last 3 years (2013-2015) shows:

Table 1.

Semarang City Art Group Ratio 2013-2015

\begin{tabular}{|c|c|c|c|}
\hline Description & \multicolumn{3}{|c|}{ Year } \\
\cline { 2 - 4 } & 2013 & 2014 & 2015 \\
\hline \hline $\begin{array}{c}\text { Number of Arts } \\
\text { Groups }\end{array}$ & 200 & 354 & 415 \\
\hline Total population & 1.581 .014 & 1.583 .188 & 1.596 .036 \\
\hline $\begin{array}{c}\text { Ratio / 10,000 } \\
\text { population }\end{array}$ & 1,26 & 2,23 & 2,60 \\
\hline
\end{tabular}

Source: Department of Culture and Tourism Office Semarang City, 2015

However, considered from the ratio of the number of art groups to 10,000 populations, it is still relatively small. (We can observe this phenomenon from the number of art groups in Semarang City 415 by 2015 , as well as the ratio of the number of art groups per 10.000 population of Semarang City from 2.60 in)

According to the previous described fact, to investigate how the role of CTO of Semarang City, especially Culture Sector in dealing with cultural values erosion of the people in Semarang City which can be seen from the performance indicators achievement of CTO of Semarang City in Culture Sector/division.

The Research Objectives are :

1) To analyze the performance in handling cultural values erosion in Semarang City.

2) To describe supporting and inhibiting performance factors in dealing with the cultural values decline of the community in Semarang City.

\section{RESEARCH METHOD}

This research used descriptive qualitative approach. Interviews, documentation, and focus group disscussion (FGD) with employees of CTO of Semarang city and stake holders as the informants are some techniques used to obtain research data. The study was conducted in 2016, between June and September. Furthermore, to test the data quality and validity, the researchers used triangulation technique with the data source. Data were analyzed by taxonomic techniques.

\section{RESULT AND DISCUSSION}

\section{A. The Performance in Handling Cultural Values Erosion (CVE)}

\section{Measure of Performance}

Based on Sudarmanto [1] opinion, Organizational performance is an outcome achievement at the organizational level or unit of analysis. Performance at the organizational level is related to organizational goals, organizational design, and organizational management. The performance of organization as the achievement level of tasks or duty implementation of tasks within an organization, in order to realize the aims, goals, mission, and vision of the organization.

Performance dimensions or indicators are aspects that become measures in assessing performance. These measures are used as a benchmark in assessing the performance. Indicators of organizational performance are quantitative and qualitative measures which describe the achievement of purposes or goals based on Bastian said in Tangkilisan [2], that have been established by considering the following indicators: Inputs indicator, Outputs indicator, Outcomes indicator, Benefits indicator, and Impact indicator. Moreover, Kumorotomo in Sudarmanto formulated 4 indicators of accessing organizational performance, they are: Effecience, Effectiveness, Fairness/justice, and Responsiveness. Furthermore, Tangkilisan presented a complete measure of performance level in a public organization, i.e.:

1) Productivity,

2) Service quality,

3) Responsiveness,

4) Responsibility, and

5) Accountability.

2. Work Performance of Handling Cultural Values Erosion of the community in Semarang City

\section{a. Productivity}

Productivity of Culture Sector in this research is observed from the suitability of activity program run by Culture Sector with certain target and goals, success of activity program held by Culture Sector, and effort to increase the success of Activity program conducted by Culture Sector. Activity program of Culture Sector have averagely been suited with the targets and aims/goals set in RPJMD year 2011-2015. The research indicated that the program implementation has shown not so good results. This is evidence from the ratio of the number of art groups per 10.000 population of Semarang City only 2.60. This is due to limited budget and human resources.

\section{b. Service Quality}

The quality of service shows how the performance of an organization in properly serving the community. The form of services provided by the Culture Sector includes the service to the artists / culturalist who are members of art community / art groups such as in Raden Saleh Cultural Park and Sobokarti Art Center. The form of services provided is in the form of giving guidance, facilitating and financing cultural attractions and performances.

The obstacles faced by Culture Sector include limited human resources and budgetary, coordination and cooperation which do not match the expectations during holding big events such as Dugderan event, the submission of accountability report $(S P J)$ made by the community under the facilitation given from the Culture Sector is usually not on time, some art groups / community are not well united in preserving 
the culture, and the absence of cultural experts in Culture Sector.

Services provided have generally been not suited with the expectations of the community. Moreover, it still cannot be done thoroughly due to budget constraints and have usually been plotted for certain community. Accordingly, the satisfaction or suitability of service with the hope of the community is very relative because it depends on the community which has obtain the facilities.

\section{c. Responsiveness}

Responsiveness is the ability of Culture Sector to recognize the needs of the community, to set up the agenda and priorities of services, as well as hold the development of public service programs that suit the needs and input of the community.

Based on the research results, it can be revealed that the activities conducted by Culture Sector in order to explore the needs of the community including Musrenbang, Workshop, Seminar, Dialog, Socialization, and provision of public complaints facilities through website, email and social media. However the research indicated that coordination and cooperation which do not match the expectations during holding big events such as Dugderan event. As stated by Chia [3] that Communication, both traditional and in new media forms such as social media, was important to social capital development provided that it was diverse, appropriate to community needs and extended its reach to community members to include those who were marginalized. The attitude of Culture Sector in responding the needs of society is always open and willing to accept all input and suggestions from the community.

\section{d. Responsibility}

Responsibility term in this research is used to explain about the the duty implementation of Culture Sector as well as conformity of the executed duty implementation with the existing requirement and policy. Based on the research results, it can be revealed that the implementation of Culture Sector duty is good enough since it suited with the basic tasks and functions (tupoksi), the needs and policies arranged in plan documents such as RPJMD, Renstra (strategic Plan), and Renja.

e. Accountability

Accountability is the responsibility of an organization to its reported performance in the form of documents addressed to public officials and general public.

In accordance with the research results, it can be described that the responsibility of Culture Sector is quite good, indicated by the making of budget report documents and performance results within a certain period. In addition, the transparency and reporting of the performance results of Culture Sector is also quite good.

\section{B. Supporting and Inhibiting Factors}

Organizational performance is not only influenced by individual performance or team performance, but is also influenced by wider and more complex factors, such as internal and external environmental factors suggested these following internal and external factors. Follow the Tangkilisan [4] said there are:

1. External Factor

a. Political factor,

b. Economic factor, and

c. Social factor.

2. Internal Factor

a. Goals of Organization,

b. Structure of organization,

c. Human resources,

d. Culture of organization.

Human resources as internal factor is also stated by Adamson and Bromiley [5] that Community empowerment requires adequate training for development staff and support mechanisms for community participants. Roles of public sector organizations attending community partnerships need to be clearly defined. At an organisational level, incentives, including funding, and sanctions are needed in order to change ways of working.

In accordance with Sembiring [6], factors which influence public organizational performance are:

a) Work Load;

b) Working Paradigm;

c) 3 PFI elements (Personnel, Financing, and Infrastructure and facilities);

d) Intention and willingness to work hard

Based on previously described supporting and inhibiting factors which affect the performance of the organization, the researchers are eager to focus on only a few factors, such as:

a) Internal environmental factors include:

1) Organizational Goals/objectives.

2) Organizational Structure.

3) Human Resources.

4) Organizational Culture.

b) External environmental factors include:

1) Political Factors.

2) Economic Factors.

3) Social Factors.

Community involvement as the external factor is also stated by Henderson [7], who mentioned that community care practice and strategies need to relate to the Government's social inclusion policies by broadening the agenda and by showing clear commitment to community involvement. Thus, in implementing the agenda of Culture Sector of CTO in Semarang city, it is important to involve Semarang community.

Culture or budaya is derived from the Sanskrit language, buddhaya, and is the plural form of buddhi (mind and thought, interpreted as any matters relating to the mind and human thought. In English, culture is derived from the Latin word Colere, meaning to cultivate the land or farming. Culture is sometimes translated as "kultur" in the Indonesian language. 
Wahyu [8] said that culture can be defined as the whole thoughts and objects created or created by humans in their history development.

Based on the research results, the followings are supporting and triggering factors of Culture Sector performance as seen in figure 1:

Figure 1

Taxsonomic of Supporting and Inhibiting Factor of Culture Sector Performance

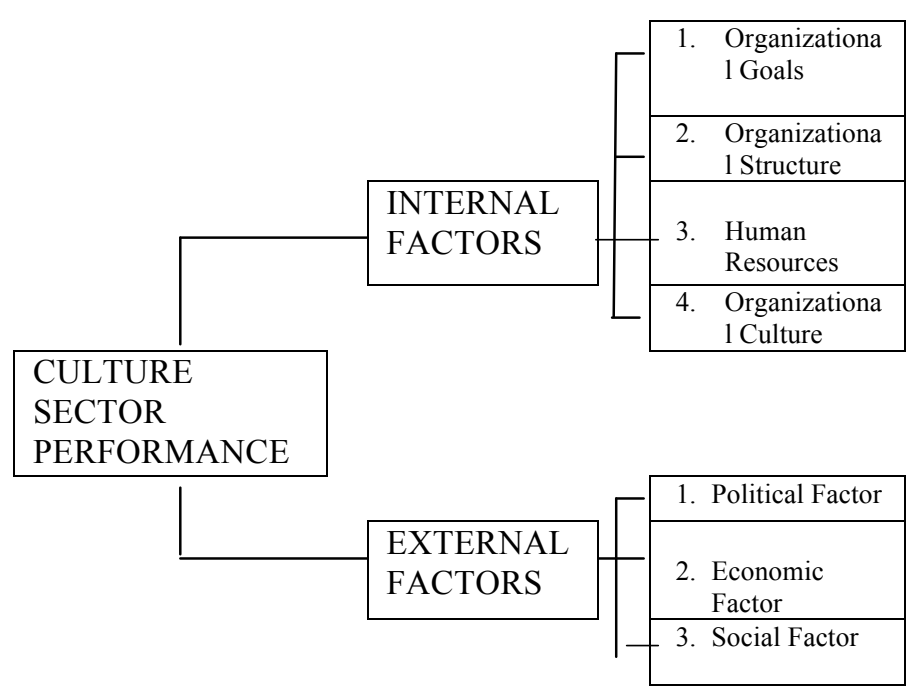

Source: processed from researchers' interview results

By knowing those previously mentioned supporting and inhibiting factors, these are some alternative ways to enhance community development, the work performance and to decrease cultural value in the community. Follow Gilchrist [9] opinion, they are :

1. Enabling people to become involved by removing practical barriers

2. Encouraging individuals to contribute to activities and decision-making

3. Empowering them by increasing confidence and the ability to influence decisions

4. Educating people by helping them to reflect, learn from others and discuss

5. Equalizing situations so people have equal access to opportunities and resources

6. Evaluating the impact of these interventions

7. Engaging with groups and organisations to increase community involvement

Based on the research results table, the supporting and triggering factors of Culture Sector performance are the objectives in Strategic Plan (Renstra) of CTO of Semarang city year 2010-2015, excellent organizational structure, adequate human resources quality, discipline and mutual cooperation attitude, policies in RPJMD (middle term plan), community economic condition and the existence of budget, high community participation during big events, and Criticism and public advice. While the inhibiting factors are limited human resources, central and local government regulations which are so strict about grant funding, lack of authority in national cinema, cultural heritage certification, and preservation of Javanese language, limited budgets, and lack of participation, interest and awareness of the community towards culture preservation.

\section{CONCLUSION}

Research result shows that the work performance of Culture Sector of CTO in Semarang City in handling cultural values erosion of society in Semarang city is relatively quite good, yet it is still not maximal because there is still constraints on dimension of productivity and service quality, i.e. the lack of coordination and cooperation as well as the lack of public participation. The supporting factors are the objectives in Strategic Plan (Renstra) of CTO of Semarang city year 2010-2015, excellent organizational structure, adequate human resources quality, discipline and mutual cooperation attitude, policies in RPJMD (midle term plan), community economic condition and the existence of budget, high community participation during big events, and Criticism and public advice. While the inhibiting factors are limited human resources, central and local government regulations which are so strict about grant funding, lack of authority in national cinema, cultural heritage certification, and preservation of Javanese language, limited budgets, and lack of participation, interest and awareness of the community towards culture preservation.

\section{REFERENCES}

[1] Sudarmanto, Performance \& Competency Development . Pustaka Pelajar: Yogyakarta, 2009.

[2] Tangkilisan, and Hessel Nogi. Public Management. Grasindo: Jakarta, 2005.

[3] C. Joy, Communicating, connecting And developing social Capital for organizations And their communities: Benefits for socially Responsive organizations, 2014. www.emeraldinsight.com downloaded by University of British Columbia Library on January 31, 2016.

[4] Tangkilisan, and H. Nogi. Public Management. Grasindo: Jakarta, 2005 .

[5] D. Adamson and R. Bromiley, Community Empowerment: Learning from Practice in Community Regeneratio, 2013. www.emeraldinsight.com downloaded by Arizona University on December 17, 2014.

[6] M. Sembiring. Culture and Organizational Performance. Fokus Media: Bandung, 2012.

[7] Henderson, Paul, Caring communities and community development: How can care and community mix?, 2000. www.emeraldinsight.com downloaded by New York University on March 1, 2016.

[8] Wahyu, Ramdani. Basic Cultural Science. CV. Pustaka Setia: Bandung, 2008.

[9] Gilchrist, AThe Well-connected Community. Bristol: The Policy Press, 2004. 